\title{
Ukuran Perusahaan Memoderasi Pengaruh Profitabilitas, Free Cash Flow, dan Likuiditas pada Kebijakan Dividen
}

\author{
Made Dita Wahyuni' ${ }^{1}$ \\ Fakultas Ekonomi dan Bisnis \\ Universitas Udayana, Indonesia \\ Email: ditawahyuni12@gmail.com
}

\author{
I Dewa Nyoman Badera ${ }^{2}$ \\ Fakultas Ekonomi dan Bisnis \\ Universitas Udayana, Indonesia
}

\begin{abstract}
ABSTRAK
Kebijakan dividen merupakan keputusan perusahaan untuk menentukan apakah laba yang diperoleh perusahaan akan dibagikan kepada pemegang saham dalam bentuk dividen a tau akan dijadikan sebagai laba ditahan. Perusahaan harus memerhatikan faktor-faktor dalam menentukan kebijakan dividen. Penelitian ini bertujuan untuk menganalisis pengaruh profitabilitas, free cash flow, dan likuiditas pada kebijakan dividen dengan ukuran perusahaan sebagai variabel moderasi. Penelitian ini dilakukan pada perusahaan infrastruktur, utilitas, dan transportasi yang terdaftar di Bursa Efek Indonesia tahun 2016 2018. Metode penelitian sampel yang digunakan a dalah purposive sampling. Teknik analisis data yang digunakan adalah Moderated Regression Analysis. Berdasarkan hasil penelitian, diketahui bahwa profitabilitas dan ukuran perusahaan tidak berpengaruh pada kebijakan dividen, sedangkan free cash flow dan likuiditas berpengaruh positif pada kebijakan dividen. Penelitian ini juga menemukan hasil bahwa ukuran perusahaan memperkuat pengaruh profitabilitas, free cash flow, dan likuiditas pada kebijakan dividen.
\end{abstract}

Kata Kunci: Profitabilitas; Free Cash Flow; Likuiditas; Kebijakan Dividen; Ukuran Perusahaan.

\section{Firm Size Moderates the Effect of Profitability, Free cash flow, and Liquidity on Dividend Policy}

\begin{abstract}
Dividend policy is the company's decision to determine whether profits derived by the company will be distributed to shareholders in the form of dividends or will be used as retained earnings. Companies must pay attention to factors in determining dividend policy. This study aims to analyze the iinfluence of the effect of profitability, free cash flow, and liquidity on dividend policy with firm size as a moderating variable. This research was conducted at infrastructure, utilities, and transportation companies listed on the Indonesia Stock Exchange in 2016-2018. The sample research method used was purposive sampling. The data analysis technique used is Moderated Regression Analysis. Based on the results of the study, it is known that profitability and firm size do not affect dividend policy, meanwile free cash flow and liquid ity have a positive effect on dividend policy. This study also found that firm size can strengthen the effect of profitability, free cash flow, and liquidity on dividend policy.
\end{abstract}

Keywords: $\quad$ Profitability; Free Cash Flow; Liquidity; Dividend Policy; Firm Size.

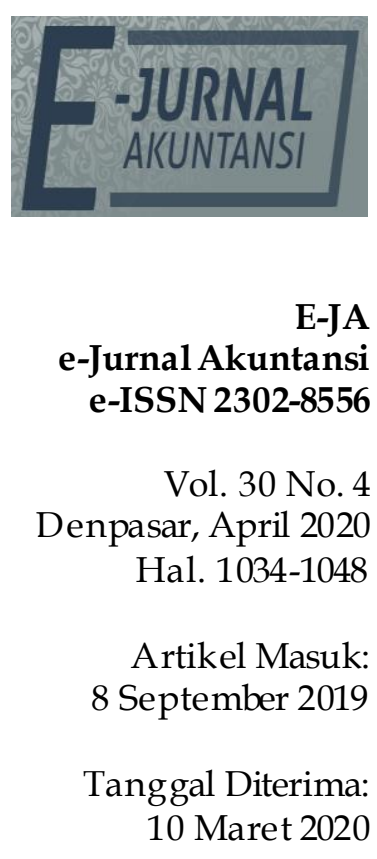

E-JA

-

o. 4

Hal. 1034-1048

Artikel Masuk:

Tanggal Diterima:

10 Maret 2020 


\section{PENDAHULUAN}

Kebijakan dividen merupakan keputusan perusahaan untuk menentukan apakah laba yang diperoleh perusahaan pada akhir tahun akan dibagikan kepada pemegang saham dalam bentuk dividen atau dijadikan saldo laba ditahan untuk investasi di masa yang akan datang (Yunisari \& Ratnadi, 2018). Kebijakan dividen merupakan suatu keputusan yang penting dan sulit bagi pihak manajemen perusahaan, karena pembagian dividen di satu sisi akan memenuhi harapan investor untuk mendapatkan return sebagai keuntungan dari inves tasi yang dilakukannya, sedangkan di sisi lain bagi perusahaan dengan pembagian dividen diharapkan tidak akan menghambat pertumbuhan perusahaan karena pembagian dividen akan mengurangi kas perusahaan sehingga dana yang tersedia untuk membiayai kegiatan operasi maupun investasi akan berkurang. Manajemen dituntut agar bisa menjaga keseimbangan antara kelangsungan hidup perusahaan dan kepentingan investor.

Terdapat beberapa fenomena yang terjadi dalam perusahaan sektor infrastruktur, utilitas, dan transportasi yang mengalami fluktuatif pada pembagian dividen. Berikut ini pada Tabel 1. merupakan data dividend payout ratio dari beberapa perusahaan sektor infrastruktur, utilitas, dan trans portasi di Indonesia.

Tabel 1. Dividend payout ratio Perusahaan Infrastruktur, Utilitas, dan Transportasi Periode 2016-2018

\begin{tabular}{lccc}
\hline \multicolumn{1}{c}{ Nama Perusahaan } & \multicolumn{3}{c}{ Dividendpayoutratio (\%) } \\
& 2016 & 2017 & 2018 \\
\hline Cardig Aero Services Tbk. & 10,01 & 24,99 & 16,61 \\
Rukun Raharja Tbk. & 11,43 & 12,85 & 0,00 \\
Sarana Menara Nusantara Tbk. & 23,03 & 57,14 & 17,94 \\
Nusantara Infrastructure Tbk. & 0,00 & 49,21 & 0,00 \\
Adi Sarana Armada Tbk. & 38,29 & 39,51 & 28,66 \\
\hline
\end{tabular}

Sumber: Bursa Efek Indonesia, 2019

Tabel 1. menunjukkan bahwa nilai dividend payout ratio pada beberapa perusahaan infrastruktur, utilitas, dan transportasi mengalami trend yang fluktuatif, bahkan beberapa perusahaan tidak membagikan dividen. Fenomena tersebut menunjukkan bahwa ada beberapa faktor yang memengaruhi kebijakan dividen perusahaan infrastruktur, utilitas, dan transportasi. Investor pasti menginginkan adanya tingkat pengembalian yang lebih tinggi dibandingkan pengorbanan yang telah dikeluarkan untuk mendapatkan investasi tersebut. Oleh karena itu, dividen menjadi salah satu pertimbangan bagi investor untuk menanamkan modalnya disuatu perusahaan untuk mendapatkan pengembalian investasi Sari \& Budiasih (2016).

Berdasarkan agency theory yang dikemukakan oleh Jensen \& Meckling, (1976) menyatakan bahwa adanya hubungan antara satu orang atau lebih (principal) mempekerjakan orang lain (agen) untuk memberikan suatu jasa dan kemudian mendelegasikan wewenang dalam pengambilan keputusan kepada agen tersebut. Manajemen sebagai pengelola perusahaan wajib memberikan informasi mengenai kondisi perusahaan kepada pemilik karena manajemen dipandang memiliki informasi lebih banyak tentang nilai aset dan peluang dibandingkan pemegang saham (Handriani \& Robiyanto, 2018). Agency problem 
antara principal dan agen terjadi karena pihak principal khawatir jika perusahaan memiliki kas dalam jumlah besar akan dialokasikan pada sumber daya yang tidak efisien dan digunakan untuk melakukan investasi yang tidak menguntungkan. Salah satu cara untuk meminimumkan kos keagenan akibat timbulnya agency problem tersebut maka pihak agen dapat melakukan pembayaran dividen pada pemegang saham.

Indikator utama dari kemampuan perusahaan untuk membayar dividen adalah kemampuan perusahaan memperoleh laba, sehingga rasio profitabilitas dianggap sebagai faktor penentu terpenting terhadap kebijakan dividen (Marietta \& Sampurno, 2013). Bagi pemimpin perusahaan, profitabilitas bisa menjadi tolak ukur keberhasilan dari manajemen perusahaan. Sedangkan bagi para pemegang saham, profitabilitas mampu menjadi sinyal dan merupakan salah satu faktor yang menjadi pertimbangan dalam melakukan inves tasi pada perusahaan.

Pembayaran dividen khususnya dividen tunai juga sangat tergantung pada posisi kas yang tersedia dalam perusahaan. Kebijakan dividen dapat mengurangi aliran kas bebas yang tersedia bagi manajer untuk melakukan investasi (Marietta \& Sampurno, 2013). Terlalu banyak free cash flow dapat mengakibatkan terjadinya konflik keagenan antara pemegang saham dengan pihak manajemen karena terdapat perbedaan kepentingan.

Rasio likuiditas adalah rasio yang menunjukkan kemampuan perusahaan untuk memenuhi kewajibannya yang bersifat jangka pendek. Perusahaan untuk dapat memengaruhi kewajiban jangka pendeknya harus memiliki alat-alat untuk membayar berupa aset lancar yang jumlahnya harus jauh lebih besar daripada kewajiban-kewajiban lancar yang harus segera dibayar (Bamaisyarah \& Fuadati, 2017). Semakin besar kas yang dimiliki perusahaan maka semakin besar kemampuan perusahaan untuk membayar utangnya yang kemudian akan memengaruhi kemampuan perusahaan dalam membayar dividen.

Ukuran perusahaan adalah skala besar kecilnya suatu perusahaan. Besar kecilnya suatu perusahaan dapat ditunjukkan oleh aktiva, jumlah penjualan, rata-rata total penjualan, dan rata-rata total aktiva (Trisna \& Gayatri, 2019). Kemampuan perusahaan besar untuk memperoleh dana lebih besar mengakibatkan perusahaan besar mampu memiliki dividend payout ratio lebih tinggi daripada perusahaan kecil. Tujuan penelitian ini adalah untuk mendapatkan bukti empiris mengenai pengaruh profitabilitas, free cash flow, $\mathrm{d}$ an likuiditas pada kebijakan dividen dengan menambahkan variabel ukuran perusahaan sebagai variabel moderasi. Pemilihan ukuran perusahaan sebagai variabel moderasi bermaksud untuk menguji apakah variabel ini nantinya dapat memperkuat atau memperlemah profitabilitas, free cash flow, dan likuiditas terhadap kebijakan dividen. Semakin besar ukuran perusahaan maka ada kecenderungan bahwa lebih banyak investor yang tertarik pada perusahaan tersebut karena dianggap memiliki kondisi keuangan yang lebih stabil (Nur, 2018). 


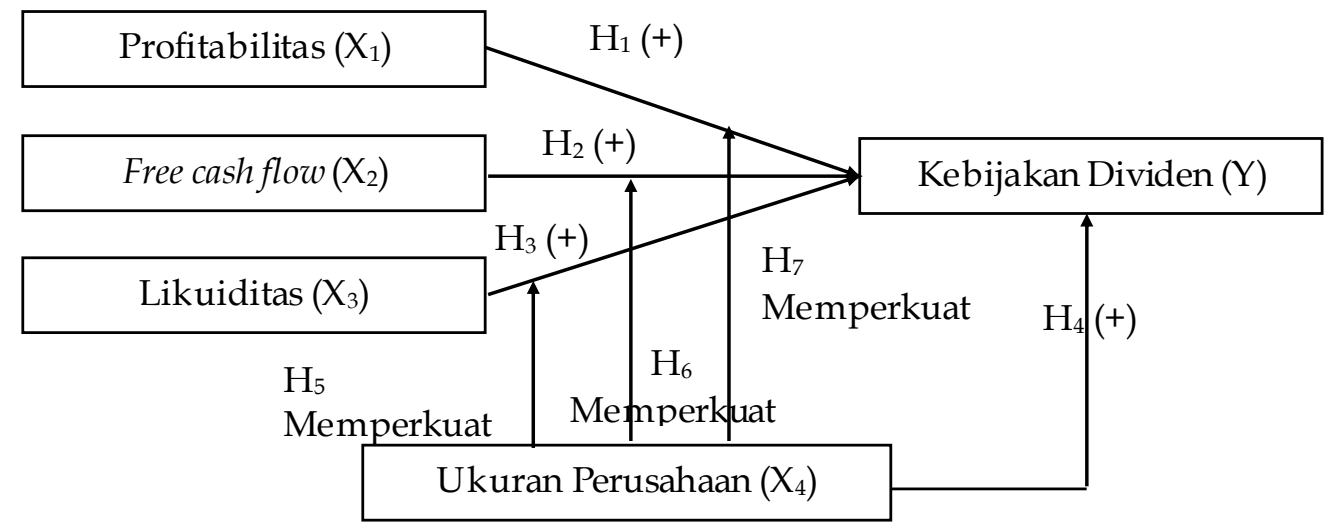

Sumber: Data Penelitian, 2019

Gambar 1. Model Penelitian

Bhattacharya (1979) menjelaskan tentang pembayaran dividen yang optimal sebagai sinyal dari profitabilitas di masa depan. Kemampuan perusahaan dalam melakukan pembayaran dividen dapat menjadi sinyal bagi investor. Sesuai dengan teori sinyal, dimana peningkatan kebijakan dividen dapat memberikan sinyal kepada para investor mengenai prospek perusahaan dan gambaran masa depan perusahaan yang baik. Peningkatan pembayaran dividen oleh perusahaan dapat dianggap sebagai sinyal positif oleh investor yang menggambarkan kondisi perusahaan memiliki prospek yang baik kedepannya.

Penelitian terdahulu yang dilakukan oleh Bansaleng et al. (2014), Yunisari \& Ratnadi (2018), Awad (2015), Elmi \& Muturi (2016), serta Utama \& Gayatri (2018) menemukan hasil bahwa profitabilitas berpengaruh positif pada kebijakan dividen.

Kebijakan dividen tidak dapat dipisahkan dari profitabilitas suatu perusahaan karena pembagian dividen bergantung pada jumlah laba yang mampu dicapai perusahaaan. Profitabilitas yang meningkat akan meningkatkan kemampuan perusahaan dalam melakukan pembayaran dividen kepada pemegang saham. Berdasarkan alasan tersebut, hipotesis yang dapat dikembangkan dalam penelitian ini adalah:

$\mathrm{H}_{1}$ : Profitabilitas berpengaruh positif pada kebijakan dividen.

Berdasarkan teori agensi, biaya keagenan dapat diminimalkan dengan suatu mekanisme pengawasan untuk mensejajarkan kepentingan antara pemegang saham dengan manajer seperti dengan melakukan pembagian dividen kepada pemegang saham sehingga dana berlebih atau aliran kas bebas yang dimiliki perusahaan tidak akan disalahgunakan oleh pihak internal.

Penelitian yang dilakukan oleh Sari \& Budiasih (2016) serta Suartawan \& Yasa (2016) mendukung teori tersebut dimana hasil penelitian menunjukkan free cash flow berpengaruh positif pada kebijakan dividen.

Apabila free cash flow perusahaan tinggi maka akan menghasilkan dividen yang tinggi pula. Hal ni dikarenakan perusahaan yang memiliki free cash flow tinggi akan berusaha menekan agency cost guna membuktikan bahwa arus kas bebas perusahaan tidak akan disalahgunakan oleh pihak internal. Agency cost dapat diminmalkan dengan melakukan pembagian dividen kepada pemegang saham. Berdasarkan alasan tersebut, hipotesis yang dapat dikembangkan dalam penelitian ini adalah: 
$\mathrm{H}_{2}$ : Free cash flow berpengaruh positif pada kebijakan dividen.

Apabila nilai dari likuiditas meningkat, maka ini berarti bahwa perusahaan mampu untuk mengatasi kewajiban jangka pendeknya dengan baik dan hal ini dapat dijadikan sinyal bagi pihak manajemen untuk menarik minat para investor untuk melakukan investasi pada perusahaan tersebut.

Penelitian yang dilakukan oleh Ahmed (2015), Wahyuni (2015) dan Lestari et al. (2016) yang menyimpulkan bahwa likuiditas berpengaruh positif terhadap kebijakan dividen.

Meningkatnya likuiditas perusahaan menunjukkan bahwa akan semakin besar kemungkinan pembayaran dividen yang akan dilakukan oleh perusahaan. Hal ini disebabkan karena semakin tinggi likuiditas pada suatu perusahaan menunjukkan semakin besar kemampuan perusahaan untuk membayar kewajiban jangka pendeknya dengan menggunakan aktiva lancar berupa kas, piutang, investasi jangka pendek, persediaan dan beban dibayar dimuka (Yosephine \& Tjun, 2016). Berdasarkan alasan tersebut, hipotesis yang dapat dikembangkan dalam penelitian ini adalah:

$\mathrm{H}_{3}$ : Likuiditas berpengaruh positif pada kebijakan dividen.

Perusahaan besar yang sudah mapan akan memiliki akses yang mudah menuju pasar modal, sedangkan perusahaan baru dan tergolong masih kecil akan menghadapi banyak kesulitan untuk memiliki akses ke pasar modal (Arjana \& Suputra, 2017). Hal ini merupakan sinyal bagi para investor untuk melakukan investasi terhadap perusahaan-perusahaan besar tersebut.

Penelitian yang dilakukan oleh Jaara et al. (2018), Devi \& Erawati (2014) serta Arjana \& Suputra (2017) menyatakan bahwa ukuran perusahaan berpengaruh positif pada kebijakan dividen.

Perusahaan besar cenderung membagikan dividen dalam jumlah tinggi untuk menjaga reputasi dimata investor. Perusahaan besar akan lebih mudah dalam memperoleh pendanaan di pasar modal daripada perusahaan kecil (Mehta, 2012). Perusahaan besar akan memberikan pembayaran dividen yang tinggi, karena perusahaan besar tentu lebih stabil dalam menghasilkan laba, serta lebih mampu memanfaatkan sumber daya yang dimilikinya daripada perusahaan kecil. Perusahaan kecil lebih memilih untuk menggunakan laba yang diperoleh dialokasikan pada laba ditahan untuk menambah aset perusahaaan. Berdasarkan alasan tersebut, hipotesis yang dapat dikembangkan dalam penelitian ini adalah:

$\mathrm{H}_{4}$ : Ukuran perusahaan berpengaruh positif pada kebijakan dividen.

Besar kecilnya profitabilitas perusahaan bergantung pada laba bersih yang dihasilkan yang dibandingkan dengan total aset yang dimiliki perusahaan. Semakin besar profitabilitas yang dimiliki perusahaan maka semakin besar peluang perusahaan tersebut untuk membagikan dividen kepada para pemegang saham. Semakin besar ukuran perusahaan maka ada kecend er ungan bahwa lebih banyak investor yang tertarik pada perusahaan tersebut karena dianggap memiliki kondisi keuangan yang lebih stabil (Nur, 2018)

Penelitian yang dilakukan oleh Bansaleng et al. (2014), Arjana \& Suputra (2017), Yunisari \& Ratnadi (2018), serta Utama \& Gayatri (2018) menemukan hasil bahwa profitabilitas berpengaruh positif pada kebijakan dividen sedangkan penelitian yang dilakukan oleh Kaźmierska \& Jóźwiak (2015), Thirumagal \& 
Vasantha (2017), serta Anjarsari et al. (2018) yang memperoleh hasil bahwa profitabilitas berpengaruh negatif pada kebijakan dividen.

Perusahaan besar diperkirakan akan mampu membayar dividen yang lebih tinggi dibandingkan dengan perusahaan kecil. Perusahaan besar dianggap lebih stabil dalam menghasilkan laba, serta lebih mampu memanfaatkan sumber daya yang dimilikinya daripada perusahaan kecil (Devi \& Erawati, 2014). Semakin besar laba yang dihasilkan perusahaan maka peluang untuk membagikan keuntungan dalam bentuk dividen akan semakin besar. Berdasarkan alasan tersebut, hipotesis yang dapat dikembangkan dalam penelitian ini adalah:

$\mathrm{H}_{5}$ : Ukuran perusahaan memperkuat pengaruh profitabilitas pada kebijakan dividen.

Semakin besar arus kas bebas yang tersedia dalam suatu perusahaan, maka perusahaan tersebut dapat dikatakan sehat karena memiliki kas yang tersedia untuk pertumbuhan, pembayaran utang maupun untuk dividen. Perusahaan dengan free cash flow yang tinggi akan mendapat tekanan dari investor untuk membagikannya dalam bentuk dividen guna mencegah manajemen melakukan hal-hal yang tidak sesuai.

Penelitian yang dilakukan oleh Sari \& Budiasih (2016) serta Suartawan \& Yasa (2016) menyatakan bahwa free cash flow berpengaruh positif terhadap kebijakan dividen. Hasil yang berbeda didapatkan dari penelitian Kargar \& Ahmadi (2013), Adnan et al. (2014) serta Utama \& Gayatri (2018) yang menyatakan bahwa free cash flow berpengaruh negatif pada kebijakan dividen.

Perusahaan yang tergolong besar memiliki free cash flow yang lebih tinggi dibandingkan perusahaan yang tergolong kecil. Hal ini terjadi karena pada perusahaan yang berukuran besar, arus kasnya sudah positif sehingga memiliki prospek yang baik untuk jangka waktu yang lama, stabilitas yang lebih baik, serta lebih mampu menghasilkan laba dibandingkan perusahaan kecil. Hal ini sesuai dengan peneltian yang dilakukan (Sunarya, 2013). Berdasarkan uraian diatas maka hipotesis penelitian ini adalah sebagai berikut.

$\mathrm{H}_{6}$ : Ukuran perusahaan memperkuat pengaruh free cash flow pada kebijakan dividen.

Ukuran perusahaan berhubungan dengan fleksibilitas dan kemampuan perusahaan untuk mendapatkan dana dan memperoleh laba dengan melihat pertumbuhan penjualan perusahaan. Kemampuan perusahaan untuk membayar dividen dapat menjadi sinyal kepada investor bagaimana perusahaan dapat mengelola dana yang dimilikinya hingga dapat melunasi kewajiban jangka pendeknya.

Penelitian yang dilakukan oleh Ahmed (2015), Wahyuni (2015) serta Lestari et al. (2016) yang menyimpulkan bahwa likuiditas berpengaruh positif terhadap kebijakan dividen. Disisi lain Michaely \& Qian (2017) serta Wicaksono \& Nasir (2014) menyimpulkan likuiditas berpengaruh negatif terhadap kebijakan dividen.

Semakin besar kas yang dimiliki perusahaan maka semakin besar kemampuan perusahaan untuk membayar kewajiban jangka pendeknya seperti membayar dividen. Perusahaan dengan ukuran besar lebih likuid karena tingginya permintaan saham. Semakin besar ukuran suatu perusahaan maka 
semakin besar pula ketersediaan kas perusahaan, sehingga semakin besar pula dividen yang dapat dibayarkan perusahaan (Nur, 2018). Berdasarkan uraian diatas maka hipotesis penelitian ini adalah sebagai berikut.

$\mathrm{H}_{7}$ : Ukuran perusahaan memperkuat pengaruh likuiditas pada kebijakan dividen.

\section{METODE PENELITIAN}

Penelitian ini menggunakan pendekatan kuantitatif yang berbentuk penelitian asosiatif dengan tipe kausalitas. Lokasi penelitian ini dilakukan pada perusahaan infrastruktur, utilitas, dan transportasi yang terdaftar di Bursa Efek Ind onesia. Objek dalam penelitian ini adalah kebijakan dividen yang dijelaskan dengan profitabilitas, free cash flow, dan likuiditas.

Kebijakan dividen adalah keputusan apakah laba yang diperoleh perusahaan akan dibagikan kepada pemegang saham atau akan ditahan dalam bentuk laba ditahan guna pembayaran investasi di masa mendatang (Sartono, 2010: 289).

$$
\text { DPR }=\frac{\text { Dividend per Share }}{\text { Earning per Share }} \times 100 \%
$$

Profitabilitas menunjukkan kemampuan perusahaan dalam menghasilkan laba (Wiagustini, 2014: 90). Profitabilitas dalam penelitian ini diproksikan dengan Return on Asset (ROA).

Profitabilitas $=\frac{\text { Laba Bersih }}{\text { Total Aset }} \times 100 \%$

Free cash flow adalah aliran kas yang masih tersisa dari aktivitas pendanaan semua proyek yang menghasilkan Net Present Value (NPV) positif (Utama \& Gayatri, 2018).

Free cash flow $=\mathrm{OCF}-(\mathrm{NCE}+\mathrm{NWC})$

Total aset

Keterangan :

OCF $=$ Operating Cash Flow

$\mathrm{NCE}=$ Net Capital Expenditures

NWC $=$ Net Working Capital

Likuiditas perusahaan menunjukkan kemampuan perusahaan untuk membayar kewajiban jangka pendek tepat pada waktunya (Hanafi \& Halim, 2018: 75). Likuiditas dalam penelitian ini menggunakan current ratio.

$$
\text { Likuiditas }=\frac{\text { Aktiva Lancar }}{\text { Kewajiban Lancar }} \times 100 \%
$$

Variabel moderasi dalam penelitian ini adalah ukuran perusahaan yang diukur dengan menggunakan Logaritma natural (Ln) dari total aset (Khalid \& Rehman, 2015).

Size $=$ Ln $($ Total Aset $)$

Populasi dari penelitian ini adalah perusahaan infrastruktur, utilitas, dan transportasi yang terdaftar di Bursa Efek Indonesia pada periode 2016 sampai 2018. Metode pengambilan sampel yang digunakan adalah metode non probability sampling dengan teknik purposive sampling. Kriteria yang digunakan dalam menentukan sampel pada penelitian ini adalah perusahaan infrastruktur, utilitas, dan transportasi di BEI yang membagikan dividen berturut-turut pada 
tahun 2016-2018. Berdasarkan kriteria pengambilan sampel yang digunakan dalam penelitian ini hanya 12 perusahaan yang memenuhi kriteria sampel dari 70 populasi yang ada sedangkan sisanya sebanyak 58 perusahaan tidak memenuhi kriteria karena perusahaan tersebut tidak membagikan dividen secara berturut-turut dari tahun 2016-2018. Metode pengumpulan data dalam penelitian ini adalah metode observasi non partisipan atau metode dokumentasi.

Teknik analisis data yang digunakan dalam penelitian ini adalah Moderated Regression Analysis (MRA). Persamaan regresi seperti berikut ini. $Y=\alpha+\beta_{1} X_{1}+\beta_{2} X_{2}+\beta_{3} X_{3}+\beta_{4} X_{4}+\beta_{5} X_{1}{ }^{*} X_{4}, \beta_{6} X_{2}{ }^{*} X_{4}, \beta_{7} X_{3}{ }^{*} X_{4}+e$

Keterangan

$\begin{array}{ll}\mathrm{Y} & : \text { Kebijakan Dividen } \\ \mathrm{X}_{1} & \text { : Profitabilitas } \\ \mathrm{X}_{2} & : \text { Free cash flow } \\ \mathrm{X}_{3} & \text { : Likuiditas } \\ \mathrm{X}_{4} & \text { : Ukuran Perusahaan } \\ \mathrm{X}_{1}^{*} \mathrm{X}_{4} & \text { : Interaksi antara profitabilitas dengan ukuran perusahaan } \\ \mathrm{X}_{2}{ }^{*} \mathrm{X}_{4} & : \text { Interaksi antara free cash flow dengan ukuranperusahaan } \\ \mathrm{X}_{3}{ }^{*} \mathrm{X}_{4} & : \text { Interaksi antara likuiditas dengan ukuran perusahaan } \\ \mathrm{a} & : \text { Parameter konstanta } \\ \beta_{1}, \beta_{2}, \beta_{3}, \beta_{4}, \beta_{5}, \beta_{6}, \beta_{7} & : \text { Koefisien regresi berganda } \\ \mathrm{e} & : \text { Faktor lain yang mempengaruhi variabel } \mathrm{Y}\end{array}$

\section{HASIL DAN PEMBAHASAN}

Statistik deskripsi menyampaikan informasi mengenai karakteristik variabelvariabel penelitian yang terdiri dari jumlah pengamatan, nilai minimum, nilai maksimum, nilai rata-rata (mean), dan standar deviasi. Hasil statistik deskriptif dapat dilihat pada Tabel 2. sebagai berikut.

Tabel 2. Hasil Analisis Statistik Deskriptif

\begin{tabular}{lrrrrr}
\hline \multicolumn{7}{c}{ Descriptive Statistics } \\
\hline DPR & $\mathrm{N}$ & Minimum & Maximum & \multicolumn{1}{c}{ Mean } & Std. Deviation \\
ROA & 36 & 4,831 & 106,742 & 43,55853 & 27,870240 \\
FCF & 36 & 1,236 & 16,941 & 6,73786 & 4,751016 \\
CR & 36 & $-0,619$ & 0,242 & $-0,01428$ & 0,171837 \\
SIZE & 36 & 31,556 & 603,837 & 185,38764 & 165,904823 \\
Valid N (listwise) & 36 & 12,099 & 18,564 & 15,78311 & 1,836900 \\
\hline
\end{tabular}

Sumber: Data Penelitian, 2019

Nilai minimum variabel tingkat pembayaran dividen adalah 4,831 yaitu PT Soechi Lines Tbk. pada tahun 2017, dan nilai maksimumnya adalah 106,742 yang terdapat pada PT Tower Bersama Infrastructure Tbk. pada tahun 2018. Mean untuk tingkat pembayaran dividen adalah 43,55853 dan standar deviasi adalah 27,870240 artinya bahwa data untuk tingkat pembayaran dividen cenderung homogen karena nilai standar deviasi yang kecil.

Nilai minimum variabel profitabilitas adalah 1,236 yaitu PT Samudera Indonesia Tbk pada tahun 2018, dan nilai maksimumnya adalah 16,941 yang terdapat pada PT Cardig Aero Services Tbk. pada tahun 2017. Mean untuk profitabilitas adalah 6,73786 dan standar deviasi adalah 4,751016 artiny a bahwa 
data untuk profitabilitas cenderung homogen karena nilai standar deviasi yang kecil.

Nilai minimum variabel free cash flow adalah -0,619 yaitu PT Perusahaan Gas Negara Tbk. pada tahun 2018, dan nilai maksimumnya adalah 0,242 yang terdapat pada PT Jasa Marga Tbk. pada tahun 2018. Mean untuk free cash flow adalah -0,01428 dan standar deviasi adalah 0,171837 artinya bahwa data untuk free cash flow cukup bervariasi (data heterogen).

Nilai minimum variabel likuiditas adalah 31,556 yaitu PT Tower Bersama Infrastructure Tbk. pada tahun 2018, dan nilai maksimumnya adalah 603,837 yang terdapat pada PT Pelayaran Nelly Dwi Putri Tbk. pada tahun 2017. Mean untuk likuiditas adalah 185,38764 dan standar deviasi adalah 165,904823 ar tinya bahwa data untuk likuiditas cenderung homogen karena nilai standar deviasi yang kecil.

Nilai minimum variabel ukuran perusahaan adalah 12,099 yaitu PT Telekomunikasi Indonesia Tbk. pada tahun 2016, dan nilai maksimumnya adalah 18,564 yang terdapat pada PT Perusahaan Gas Negara Tbk. pada tahun 2018. Mean untuk ukuran perusahaan adalah 15,78311 dan standar deviasi adalah 1,836900 artinya bahwa data untuk ukuran perusahaan cenderung homogen karena nilai standar deviasi yang kecil.

Tabel 3. Hasil Uji Asumsi Klasik

\begin{tabular}{lccccc}
\hline \multirow{2}{*}{ Keterangan } & Uji & \multicolumn{2}{c}{ Uji } & Uji & Uji \\
& Normalitas & Multikolonieritas & Heteroskedastisitas & Autokorelasi \\
\cline { 2 - 6 } & Sig. & Tolerance & VIF & Sig. & Sig. \\
\hline ROA $\left(\mathrm{X}_{1}\right)$ & & 0,674 & 1,484 & 0,061 & \\
FCF $\left(\mathrm{X}_{2}\right)$ & & 0,905 & 1,105 & 0,055 & \\
CR $\left(\mathrm{X}_{3}\right)$ & & 0,832 & 1,201 & 0,457 & \\
SIZE $\left(\mathrm{X}_{4}\right)$ & 0,794 & 0,682 & 1,467 & 0,219 & 0,398 \\
ROA ${ }^{*}$ SIZE $\left(\mathrm{X}_{1} \mathrm{X}_{4}\right)$ & & & & 0,174 & \\
FCF $\operatorname{SIZE}\left(\mathrm{X}_{2} \mathrm{X}_{4}\right)$ & & & & 0,217 & \\
CR $^{*}$ SIZE $\left(\mathrm{X}_{3} \mathrm{X}_{4}\right)$ & & & & 0,753 & \\
\hline
\end{tabular}

Sumber: Data Penelitian, 2019

Berdasarkan hasil uji normalitas pada Tabel 3. diperoleh nilai Asymp. Sig. (2-tailed) sebesar 0,794 lebih besar dari 0.05. Hal ini menunjukkan bahwa data pada model regresi yang digunakan dalam penelitian ini telah berdistribusi normal.

Berdasarkan hasil uji multikolonieritas pada Tabel 3. didapatkan nilai tolerance dan VIF dari seluruh variabel bebas yang diuji yaitu profitabilitas, free cash flow, likuiditas, dan ukuran perusahaan menunjukkan bahwa nilai tolerance untuk setiap variabel lebih besar dari 10\% dan nilai VIF lebih kecil dari 10 maka dapat dikatakan bahwa model telah bebas dari masalah multikolinearitas.

Berdasarkan uji heterokedastisitas pada Tabel 3. didapatkan nilai sig tiap variabel lebih besar dari tingkat signifikansi 0,05 yang menunjukkan bahwa model regresi yang digunakan dalam penelitian ini bebas dari gejala heteroskedastisitas.

Berdasarkan hasil uji autokorelasi dengan run tes pada Tabel 3. nilai Asymp. Sig. (2-tailed) sebesar 0,398 > 0,05 maka dapat disimpulkan tidak terjadi gejala autokorelasi. 
Tabel 4. Hasil Uji Moderated Regression Analysis (MRA)

\begin{tabular}{|c|c|c|c|c|c|}
\hline \multirow[t]{2}{*}{ Model } & \multicolumn{2}{|c|}{$\begin{array}{l}\text { Unstandardized } \\
\text { Coefficients }\end{array}$} & \multirow{2}{*}{$\begin{array}{c}\text { Standardized } \\
\text { Coefficients } \\
\text { Beta } \\
\end{array}$} & \multirow[b]{2}{*}{$\mathrm{T}$} & \multirow[b]{2}{*}{ Sig. } \\
\hline & $\mathrm{B}$ & Std. Error & & & \\
\hline (Constant) & $-0,136$ & 0,080 & & $-1,694$ & 0,101 \\
\hline ROA & 0,149 & 0,091 & 0,142 & 1,643 & 0,112 \\
\hline FCF & 0,436 & 0,092 & 0,462 & 4,745 & 0,000 \\
\hline CR & 0,380 & 0,091 & 0,399 & 4,172 & 0,000 \\
\hline SIZE & 0,144 & 0,084 & 0,138 & 1,703 & 0,100 \\
\hline ROA*SIZE & 0,131 & 0,062 & 0,163 & 2,096 & 0,045 \\
\hline FCF*SIZE & 0,242 & 0,103 & 0,238 & 2,355 & 0,026 \\
\hline$C R^{*}$ SIZE & 0,275 & 0,091 & 0,306 & 3,028 & 0,005 \\
\hline$R^{2}$ & & & & & 0,890 \\
\hline Adjusted $R^{2}$ & & & & & 0,863 \\
\hline F Statistik & & & & & 32,492 \\
\hline F Signifikansi & & & & & 0,000 \\
\hline
\end{tabular}

Sumber: Data Penelitian, 2019

berikut.

Berdasarkan Tabel 4. persamaan regresi yang terbentuk adalah sebagai

$\mathrm{Y}=-0,136+0,149 \mathrm{X}_{1}+0,436 \mathrm{X}_{2}+0,380 \mathrm{X}_{3}+0,144 \mathrm{X}_{4}+0,131 \mathrm{X}_{1} \mathrm{X}_{4}+0,242 \mathrm{X}_{2} \mathrm{X}_{4}+$ $0,275 \mathrm{X}_{3} \mathrm{X}_{4}+\varepsilon$

Berdasarkan hasil analisis pada Tabel 4. dengan tingkat signifikansi (a) sebesar 5 persen atau 0,05 menunjukkan nilai $F$ hitung sebesar 32,492 dan nilai signifikansi $\mathrm{F}$ atau p-value sebesar 0,000 lebih kecil dari $\mathrm{a}=0,05$. Hal ini menunjukkan bahwa profitabilitas, free cash flow, likuiditas, ukuran perusahaan, interaksi antara profitabilitas dengan ukuran perusahaan, interaksi antara free cash flow dengan ukuran perusahaan, dan interaksi antara likuiditas dengan ukuran perusahaan berpengaruh secara simultan pada kebijakan dividen. Maka dapat disimpulkan bahwa model regresi penelitian ini layak digunakan.

Nilai adjusted R2 adalah sebesar 0,863 artinya bahwa 86,3\% variansi dari variabel dependen, yaitu kebijakan dividen mampu dijelaskan oleh variansi variabel independen, yaitu profitabilitas, free cash flow, likuiditas, ukuran perusahaan, interaksi antara profitabilitas dengan ukuran perusahaan, interaksi antara free cash flow dengan ukuran perusahaan, dan interaksi antara likuiditas dengan ukuran perusahaan, sedangkan sisanya 13,7\% dijelaskan oleh faktor lain yang tidak dimasukkan ke dalam model.

Tabel 4. menunjukkan bahwa nilai signifikansi uji $t$ untuk variabel profitabilitas sebesar 0,112 yaitu lebih besar dari 0,05 dengan koefisien reg resi bernilai positif sebesar 0,149. Angka tersebut menandakan bahwa profitabilitas tidak berpengaruh pada kebijakan dividen sehingga hipotesis pertama ditolak. Semakin tinggi tingkat keuntungan perusahaan maka belum tentu tingkat pembagian dividen perusahaan juga akan semakin besar, sebaliknya perusahaan dengan profitabilitas yang rendah juga belum tentu tidak mampu membayarkan dividen. Seperti pada PT Jasa Marga Tbk. pada tahun 2018 membagikan divid en sebesar 21.608 juta rupiah lebih kecil dari PT Samudera Indonesia Tbk. sebesar 61.339 juta rupiah padahal profitabilitas yang didapatkan PT Jasa Marga Tbk. pada tahun 2018 sebesar 2.471 juta rupiah lebih besar dari PT Samudera Indonesia Tbk. sebesar 1.236 juta rupiah. Besar kecilnya tingkat pembayaran 
dividen pada akhirnya akan ditentukan oleh RUPS meskipun perusahaan mengalami peningkatan atau penurunan keuntungan. Hasil penelitian ini sejalan dengan penelitian yang dilakukan oleh Sari \& Sudjarni (2015) serta Sari \& Budiasih (2016) menemukan hasil bahwa profitabilitas tidak berpengaruh pada kebijakan dividen.

Tabel 4. menunjukkan bahwa nilai signifikansi uji t untuk variabel free cash flow sebesar 0,000 yaitu kurang dari 0,05 dengan koefisien regresi bernilai positif sebesar 0,436. Angka tersebut menandakan bahwa free cash flow berpengaruh positif pada kebijakan dividen sehingga hipotesis kedua diterima. Sesuai dengan teori keagenan, agency problem antara principal dan agen salah satunya terjadi karena pihak principal khawatir jika perusahaan memiliki free cash flow dalam jumlah besar akan digunakan untuk mengalokasikan pada sumber daya yang tidak efisien dan digunakan untuk melakukan investasi yang tidak menguntungkan. Terlalu banyak arus kas perusahaan akan meningkatkan masalah keagenan (Elmagrhi et al.,2017). Salah satu cara untuk meminimumkan kos keagenan akibat timbulnya agency problem tersebut maka pihak agen dapat melakukan pembagian dividen pada pemegang saham. Hasil penelitian yang sama dikemukakan oleh Sari \& Budiasih (2016) serta Suartawan \& Yasa (2016) mendukung teori tersebut dimana hasil penelitian menunjukkan free cash flow berpengaruh positif pada kebijakan dividen.

Tabel 4. menunjukkan bahwa nilai signifikansi uji $\mathrm{t}$ untuk variabel likuiditas sebesar 0,000 yaitu kurang dari 0,05 dengan koefisien regresi bernilai positif sebesar 0,380. Angka tersebut menandakan bahwa likuiditas berpengaruh positif pada kebijakan dividen sehingga hipotesis ketiga diterima. Hasil ini sesuai dengan teori sinyal yang menjelaskan bagaimana perusahaan mengungkapkan informasi kepada pihak eksternal. Perusahaan harus memiliki ketersediaan dana yang cukup berupa aset lancar perusahaan yang akan digunakan untuk membayarkan dividen. Tingginya likuiditas akan menjadi daya tarik tersendiri bagi para investor karena dapat mempengaruhi besaran dividen yang dapat dibagikan perusahaan tersebut. Hal serupa diungkapkan oleh Ahmed (2015), Wahyuni (2015) dan Lestari et al. (2016) yang memperoleh hasil bahwa likuiditas yang diproksikan dengan current ratio berpengaruh positif terhadap kebijakan dividen.

Tabel 4. menunjukkan bahwa nilai signifikansi uji $t$ untuk variabel ukuran perusahaan sebesar 0,100 yaitu lebih besar dari 0,05 dengan koefisien regresi bernilai positif sebesar 0,144. Angka tersebut menandakan bahwa ukuran perusahaan tidak berpengaruh pada kebijakan dividen sehingga hipotesis keempat ditolak. Ukuran perusahaan yang diukur berdasarkan total aset tidak dapat dijadikan pertimbangan dalam menentukan kebijakan dividen. Perusahaan besar yang lebih mudah memperoleh pendanaan di pasar modal tidak selalu membagikan dividen dalam jumlah yang besar. Perusahaan kecil juga belum tentu membagikan dividen dalam jumlah yang sedikit kepada para investornya. Seperti pada PT. Pelayaran Nelly Dwi Putri Tbk. yang membagikan dividen pada tahun 2018 sebesar 62.862 juta lebih besar dari PT Telekomunikasi Indonesia Tbk. yang membagikan dividen sebesar 61.563 juta rupiah padahal total aset yang dimiliki PT. Pelayaran Nelly Dwi Putri Tbk. sebesar 474.345 lebih sedikit dari PT Telekomunikasi Indonesia Tbk. yang memiliki total aset sebesar 
206.196.000 juta rupiah. Kebijakan dividen yang dilakukan perusahaan bergantung pada jumlah kas yang tersedia dan juga keputusan saat Rapat Umum Pemegang Saham (RUPS). Hasil penelitian ini sejalan dengan penelitian yang dilakukan Wicaksono \& Nasir (2014) serta Yosephine \& Tjun (2016) menyatakan bahwa ukuran perusahaan tidak berpengaruh pada kebijakan dividen.

Tabel 4. menunjukkan bahwa nilai signifikansi uji $t$ untuk interaksi variabel profitabilitas dengan variabel ukuran perusahaan adalah sebesar 0,045 yaitu lebih kecil dari 0,05 dengan koefisien regresi bernilai positif sebesar 0,131. Berdasarkan hal tersebut maka hipotesis kelima diterima. Artinya, ukuran perusahaan dapat memperkuat pengaruh profitabilitas pada kebijakan dividen. Perusahaan yang tergolong besar memiliki profitabilitas yang tinggi, hal ini terjadi karena perusahaan besar dianggap lebih stabil dalam menghasilkan laba, serta lebih mampu memanfaatkan sumber daya yang dimilikinya daripada perusahaan kecil (Devi \& Erawati, 2014). Semakin besar laba yang dihasilkan perusahaan maka peluang untuk membagikan keuntungan dalam bentuk dividen akan semakin besar.

Tabel 4. menunjukkan bahwa nilai signifikansi uji $\mathrm{t}$ untuk interaksi variabel free cash flow dengan variabel ukuran perusahaan adalah sebesar 0,026 yaitu lebih kecil dari 0,05 dengan koefisien regresi bernilai positif sebesar 0,242. Berdasarkan hal tersebut maka hipotesis keenam diterima. Artinya, ukuran perusahaan dapat memperkuat pengaruh free cash flow pada kebijakan dividen. Hasil penelitian ini menunjukkan bahwa perusahaan yang tergolong besar memiliki tingkat free cash flow yang tinggi, hal ini terjadi karena perusahaan besar arus kasnya positif dan memiliki prospek yang baik kedepannya diband ingkan perusahaan kecil (Trisna \& Gayatri, 2019).

Tabel 4. menunjukkan bahwa nilai signifikansi uji $t$ untuk interaksi variabel likuiditas dengan variabel ukuran perusahaan adalah sebesar 0,005 yaitu lebih kecil dari 0,05 dengan koefisien regresi bernilai positif sebesar 0,275. Berdasarkan hal tersebut maka hipotesis ketujuh diterima. Artinya, ukuran perusahaan dapat memperkuat pengaruh likuditas pada kebijakan dividen. Hasil penelitian ini didukung oleh penelitian (Sunarya, 2013) menyatakan bahwa perusahaan dengan ukuran besar lebih likuid karena tingginya pemintaan saham. Semakin besar ukuran suatu perusahaan maka semakin besar pula ketersediaan kas perusahaan, sehingga semakin besar pula kemampuan perusahaan untuk membayarkan kewajiban jangka pendeknya dan juga kemampuan perusahaan untuk membayarkan dividen.

\section{SIMPULAN}

Berdasarkan hasil analisis dan pembahasan yang telah dipaparkan pada bab sebelumnya, didapatkan simpulan sebagai berikut. 1) Profitabilitas tidak berpengaruh pada kebijakan dividen. 2) Free cash flow berpengaruh positif pada kebijakan dividen. 3) Likuiditas berpengaruh positif pada kebijakan dividen. 4) Ukuran perusahaan tidak berpengaruh pada kebijakan dividen. 5) Ukuran perusahaan memperkuat pengaruh profitabilitas pada kebijakan dividen. 6) Ukuran perusahaan memperkuat pengaruh free cash flow pada kebijakan dividen. 7) Ukuran perusahaan memperkuat pengaruh likuditas pada kebijakan dividen. 
Saran yang dapat diberikan berdasarkan hasil penelitian adalah sebagai berikut: 1) Bagi perusahaan sebaiknya menjaga tingkat free cash flow dan likuiditas agar tetap tinggi dan stabil karena salah satu tujuan investor berinvestasi adalah dengan memperoleh dividen. 2) Bagi calon investor diharapkan dapat menggunakan penelitian ini sebagai bahan pertimbangkan sebelum melakukan investasi pada suatu perusahaan. 3) Bagi peneliti selanjutnya diharapkan dapat memperluas objek penelitian dan menguji variabel lain yang dapat memengaruhi kebijakan dividen. Bagian ini berisi simpulan

\section{REFERENSI}

Adnan, M. A., Gunawan, B., \& Candrasari, R. (2014). Pengaruh profitabilitas, leverage, growth, dan free cash flow terhadap dividend payout ratio perusahaan dengan mempertimbangkan corporate governance sebagai variabel intervening. Jurnal Akuntansi \& Auditing Indonesia, 18(2), 89-100. https://doi.org/10.20885/jaai.vol18.iss2.art1

Ahmed, I. E. (2015). Liquidity, Profitability and the Dividends Payout Policy. World Review of Business Research, 5(2), 73-85.

Anjarsari, Dewi, Dheasey Amboningtyas, dan P. D. P. (2018). The Impact of Retained Earnings as an Intervening Variable in the Implementation of Free Cash Flow, Funding Policies, Profitability and Collateral Assets as a Benchmark For Dividend Policy (The empirical study of Manufacturing Companies listed on the IDX. Journal of Management. 4(4), 1-17.

Arjana, I. P. P. H., \& Suputra, I. D. G. D. (2017). Pengaruh Profitabilitas, Leverage, Ukuran Perusahaan dan Corporate Social Responsibility pada Kebijakan Dividen. E-Jurnal Akuntansi, 21(3), 2021-2051. https://doi.org/10.24843/EJA.2017.v21.i03.p12

Awad, D. B. (2015). Determinants of Dividend Policy in Kuwait Stock Exchange. International Journal of Business and Management Review, 3(7), 72-78.

Bamaisyarah, R. Y., \& Fuadati, S. R. (2017). Pengaruh Likuiditas, Aktivitas dan Ukuran Perusahaan Terhadap Profitabilitas Perusahaan Pertambangan di BEI. Jurnal Ilmu Dan Riset Manajemen, 6(3), 1-15.

Bansaleng, R. D. V, Tommy, P., \& Saerang, I. S. (2014). Kebijakan Hutang, Struktur Kepemilikan Dan Profitabilitas Terhadap Kebijakan Dividen Pada Perusahaan Food and Beverage Di Bursa Efek Indonesia. Jurnal Riset Ekonomi, Manajemen, Bisnis Dan Akuntansi, 2(3), 817-830.

Bhattacharya, S. (1979). Imperfect Information, Dividend Policy, and The Bird in The Hand Fallacy. Journal of Economics, 10(1), 259-270.

Bursa Efek Indonesia. (2019). Ringkasan Performa Perusahaan Tercatat. Diakses pada 10 Mei 2019, dari idx.co.id/data-pasar/laporan-statistik/ringkasanperforma-perusahaan-tercatat/

Devi, N. P. Y., \& Erawati, N. M. A. (2014). Pengaruh Kepemilikan Manajerial, Leverage, dan Ukuran Perusahaan kada Kebijakan Dividen Perusahaan Manufaktur. E-Jurnal Akuntansi, 9(3), 709-716.

Elmagrhi, M. H., Ntim, C. G., Crossley, R. M., Malagila, J. K., Fosu, S., \& Tien, V. (2017). Corporate Governance and Dividend Pay-out Policy in UK Listed SMEs. International Journal of Accounting \& Information Management, 25(4), 459-483. https://doi.org/10.1108/IJAIM-02-2017-0020 
Elmi, M. A., \& Muturi, W. M. (2016). Effects Of Profitability On Dividend Payout by Commercial And ServicesFirms Listed In The Nairobi Securities Exchange. European Journal of Business and Social Sciences, 5(2), 160-167.

Hanafi, M. M., \& Halim, A. (2018). Analisis Laporan Keuangan Edisi Kelima. Yogyakarta: UPPSTIM YKPN.

Handriani, E., \& Robiyanto. (2018). Corporate Finance and Firm Value in the Indonesian Manufacturing Companies. International Research Journal of Business Studies, 11(2), 113-127. https://doi.org/10.21632/irjbs.11.2.113-127

Jaara, B., Alashhab, H., \& Jaara, O. (2018). The Determinants of Dividend Policy for Non-Financial Companies in Jordan. International Journal of Economics and Financial Issues, 8(2), 198-209.

Jensen, M. C., \& Meckling, W. H. (1976). Theory of the Firm: Managerial Behavior, Agency Costs and Ownership Structure. Journal of Financial Economics 3, 3(4), 305-360. https://doi.org/https://doi.org/10.1016/0304405x(76)90026-x

Kargar, E. F., \& Ahmadi, G. R. (2013). The Relationship between Free Cash Flows and Agency Costs Levels: Evidence from Tehran Stock Exchange. Research Journal of Finance and Accounting, 4(14), 51-66.

Kaźmierska, B., \& Jozwiak. (2015). Determinants of Dividend Policy: Evidence from Polish Listed Companies. Procedia Economics and Finance, 23, 473-477. https://doi.org/10.1016/s2212-5671(15)00490-6

Khalid, S., \& Rehman, M. U. (2015). Determination of Factors effecting the Dividend policy of Organizations. International Journal of Information, Business and Management, 7(3), 319-333. https://doi.org/10.1016/j.ijinfomgt.2010.11.002

Lestari, K. F., Tanuatmodjo, H., \& Mayasari. (2016). Pengaruh Likuiditas dan Profitabilitas terhadap Kebijakan Dividen. Journal of Business Management Education, 1(2), 11-16.

Marietta, U., \& Sampurno, D. (2013). Analisis Pengaruh Cash Ratio, Return On Assets, Growth, Firm Size, Debt to Equity Ratio Terhadap Dividend Pay out Ratio : (Studi Pada Perusahaan Manufaktur Yang Terdaftar di Bursa Efek Indonesia Tahun 2008-2011). Diponegoro Journal of Management, 2(3), 1-11.

Mehta, A. (2012). An Empirical Analysis of Determinants of Dividend Policy Evidence from the UAE Companies. Global Review of Accounting and Finance, $3(1), 18-31$.

Michaely, R., \& Qian, M. (2017). Stock Liquidity and Dividend Policy: Dividend Policy Changes Following an Exogenous Liquidity Shock. SSRN Electronic Journal, 18(3), 1-42. https://doi.org/https://doi.org/10.2139/ssrn.2894164

Nur, T. (2018). Pengaruh Profitabilitas dan Likuiditas terhadap Kebijakan Dividen dengan Firm Size sebagai Pemoderasi (Pada Perusahaan Manufaktur yang Terdaftar di Bursa Efek Indonesia Periode 2013-2017). ESENSI, 21(2), 1-15.

Sari, K. A. N., \& Sudjarni, L. K. (2015). Pengaruh Likuiditas, Leverage, Pertumbuhan Perusahaan dan Profitabilitas terhadap Kebijakan Dividen pada Perusahaan Manufaktur di BEI. E-Jurnal Manajemen Universitas Udayana, 4(10), 3346-3374.

Sari, N. K. A. P., \& Budiasih, I. G. A. N. (2016). Pengaruh Kepemilikan 
Managerial, Kepemilikan Institusional, Free Cash Flow dan Profitabilitas Pada Kebijakan Dividen. E-Jurnal Akuntansi Universitas Udayana, 15(3), 24392466.

Sartono, A. (2010). Manajemen Keuangan Teori \& Aplikasi. Yogyakarta: BPPE.

Suartawan, I. G. N. P. A., \& Yasa, G. W. (2016). Pengaruh Investment Opportunity Set dan Free Cash Flow pada Kebijakan Dividen dan Nilai Perusahaan. Jumal Ilmiah Akuntansi Dan Bisnis, 11(2), 63-74. https://doi.org/10.24843/jiab.2016.v11.i02.p01

Sunarya, D. H. (2013). Pengaruh Kebijakan Utang, Profitabilitas dan Likuiditas Terhadap Kebijakan Dividen dengan Size Sebagai Variabel Moderasi pada Sektor Manufaktur. Jurnal Ilmiah Mahasiswa Universitas Surabaya, 2(1), 1-19.

Thirumagal, P. G., \& Vasantha, S. (2017). Dividend Payout Determinants : Evidence from Indian Industries. International Journal of Pure and Applied Mathematics, 117(21), 811-829.

Trisna, I. K. E. R., \& Gayatri. (2019). Ukuran Perusahaan Memoderasi Pengaruh Free Cash Flow dan Leverage Terhadap Kebijakan Dividen. E-Jurnal Akuntansi, 26(1), 454-509. https://doi.org/10.24843/eja.2019.v26.i01.p18

Utama, N. P. S. P., \& Gayatri. (2018). Pengaruh Profitabilitas, Investment Opportunity Set dan Free Cash Flow Pada Kebijakan Dividen. E-Jurnal Akuntansi, 22(2), 976-1003. https://doi.org/10.24843/EJA.2018.v22.i02.p06

Wahyuni, N. L. A. (2015). Pengaruh Profitabilitas dan Likuiditas Terhadap Besarnya Dividen yang Dibagikan kepada Pemegang Saham pada Perusahaan Manufaktur yang Terdapat di BEI. Jurnal Jurusan Pendidikan Ekonomi, 5(1). 1-10.

Wiagustini, N. L. P. (2014). Manajemen Keuangan. Denpasar: Udayana University Press.

Wicaksono, S., \& Nasir, M. (2014). Faktor-Faktor yang Mempengaruhi Kebijakan Dividen pada Perusahaan Manufaktur yang Terdaftar di Bei Periode Tahun 2011-2013. Diponegoro Journal of Accounting, 4(3), 1-13.

Yosephine, F., \& Tjun, L. T. (2016). Pengaruh Cash Ratio, Return on Equity, dan Ukuran Perusahaan Terhadap Kebijakan Dividen: Studi Empiris pada Perusahaan yang Listing Di Bursa Efek Indonesia Periode 2013-2015. Jurnal Akuntansi, 8(2), 237-269.

Yunisari, N. W., \& Ratnadi, N. M. D. (2018). Pengaruh Profitabilitas dan Kepemilikan Manajerial Pada Kebijakan Dividen dengan Likuiditas Sebagai Variabel Moderasi. E-Jurnal Akuntansi, 23(1), 379-405. https://doi.org/10.24843/eja.2018.v23.i01.p15 